\title{
Possibilities of establishing a 'small-scale geopark': examples from the area of Upper Zemplín (Slovakia)
}

Możliwość utworzenia małych geoparków: przykłady z obszaru Gór Zemplińskich (Słowacja)

\author{
Bartolomej Baláž, Lubomír Štrba \\ Technical University of Košice, BERG Faculty, Institute of Geotourism, \\ Letná 9, 04200 Košice, Slovakia; \\ e-mail:bartolomej.balaz@tuke.sk,lubomir.strba@tuke.sk
}
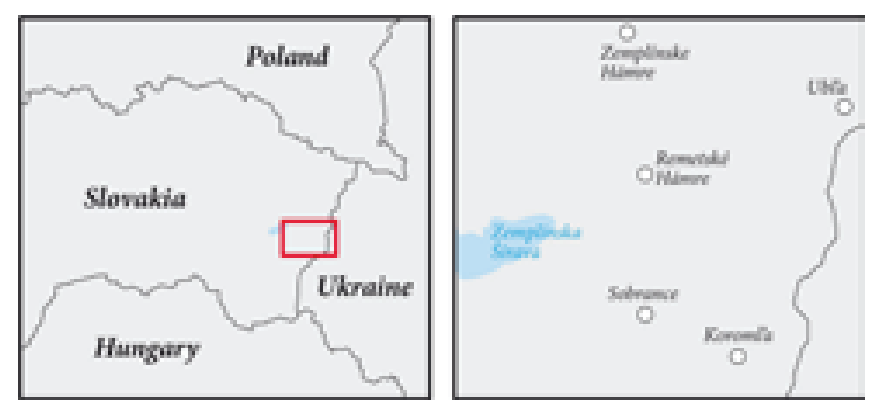

\begin{abstract}
Within relatively new forms of tourism, geotourism takes a well-established position and is developing worldwide. Hand in hand with the development of geotourism, a demand for defining different types of attractive geotourist locations or regions has arisen. Besides typical geotourist locations (geosites) and regions (geoparks), there are several areas that are geo-attractive and cover several individual geosites, but are too small to be defined as "classical" geoparks. This paper discusses an alternative approach to geotourist development by defining 'smallscale'geoparks through the example of the eastern part of Slovakia, near the border with Ukraine. The area is characterized by (1) a variegated geological structure, which includes five main geological units of the Carpathians in Slovakia, where many different-type geosites are located (e.g. mineralogical, hydrogeological, volcanological, paleontological, etc.), (2) presence of historical monuments (e.g. castle ruins), (3) botanical objects and
\end{abstract} (4) wine-producing areas.

Key words: geopark, small-scale geoparks, Zemplín, geotourism, geopark development

Treść: Pośród względnie nowych form turystyki geoturystyka zajmuje ugruntowana pozycję i rozwija się na calym świecie. Jednocześnie z rozwojem geoturystyki pojawiło się zapotrzebowanie na różne rodzaje atrakcyjnych lokalizacji lub regionów geoturystycznych. Poza typowymi obiektami i obszarami geoturystycznymi (geoparki) istnieje kilka atrakcyjnych obszarów, które sa zbyt małe, by mogty być uznane za geoparki. Niniejszy artykut przedstawia alternatywne podejście do zagospodarowania geoturystycznego w postaci , małych geoparków” na przykładzie wschodniej części Stowacji, przy granicy z Ukraina. Obszar ten charakteryzuje się: (1) zróżnicowaną budowa geologiczna, na którą składa się pięć głównych jednostek strukturalnych Karpat Stowackich, charakteryzujących się zróznicowanymi obiektami geoturystycznymi (mineralogicznymi, hydrogeologicznymi, wulkanologicznymi, paleontologicznymi, etc.), (2) obecnością zabytków historycznych (np. ruin zamków), (3) obecnościa obiektów przyrody ożywionej (roślinność) $i$ (4) obecnościa winnic.

Stowa kluczowe: geopark, małe geoparki, Zemplin, geoturystyka, zagospodarowanie geoparku

\section{Introduction}

As the concept of geotourism is rapidly growing worldwide, several activities supporting the development of this form of tourism are carried out throughout the world. In general, one of the most effective ways of developing geotourism is represented by the establishment of geoparks.

The background of the geoparks concept was introduced in France in 1991. This concept has been significantly supported by UNESCO (Division of Earth Sciences), which introduced the UNESCO Geoparks Programme in 1997 (Jones, 2008) and subsequently defined the Global Geoparks Network (GGN) in 1998. Currently, the network has 111 members from different parts of the world on all continents (GGN, 2015). Each of these members fits within the following geopark definition given by UNESCO: A Global Geopark is a unified area with geological heritage of international significance. Geoparks use that heritage to promote awareness of key issues facing society in the context of the dynamic planet we all live on. Many Geoparks promote awareness of geological hazards, including volcanoes, earthquakes and tsunamis and many help prepare disaster mitigation strategies among local communities. Geoparks hold records of past climate change and are educators on current climate change as well as adopt a best practice approach to utilising renewable energy and employing the best standards of 'green tourism' (UNESCO, 2014).

Combining principles of geoconservation, geology promotion and sustainable development, geoparks has become very important and popular tools of geotourist development worldwide. In Slovakia, the geoparks concept is supported by the Conception of the Geopark Development in Slovakia adopted by the Government of the Slovak Republic in 2008. In this document, nine geopark areas were defined within three categories - A: geoparks in operation, B: built geoparks, C: proposed geoparks. 
The Actualized Conception of Geoparks Development was under inter-ministerial review and was adopted by the Government of the Slovak Republic on 07 January 2015. This document includes ten areas of active or possible geopark areas in Slovakia. As a result of the variegated geological structure of the Carpathians in Slovakia, this country offers many geologically and/or geotouristically interesting regions, which do not fit the UNESCO definition of geoparks, but include geosites, cultural-historical sites and other features for possible geotourist development. This paper is focused on identification and characterization of significant geotourist significant sites in one of such regions located in the Upper Zemplín (eastern Slovakia).

\section{General characteristics of the area}

The study area is located in the eastern part of Slovakia, near the Slovak-Ukrainian border (Fig. 1), with dominating Vihorlatské vrchy Mts. From the geological point of view (Fig. 2), the following geological units are present in this area: Outer Carpathians Flysch, Pieniny Klippen Belt, Neogene Volcanics and East-Slovakian Neogene Basin.

The outer Carpathians Flysch is located in the north-eastern edge of the area. Its inner part (Magura Unit) is composed of Proč beds (karbonatic sandstones, claystones, locally with conglomerates) and Strihovce beds (sandstones, claystones, conglomerates, submarine slide bodies). It is possible to wash gold from weathered oligomict quartz conglomerates of the Strihovce beds in brooks in this area. Radial aggregates of dawsonite and alumohydrocalite (reaching up to $1 \mathrm{~cm}$ ) (Dud'a, Ozdín, 2012) were found in a brook channel streaming through Ladomírov village.

The Pieniny Klippen Belt is composed of tectonically complicated cliffs consisting of variegated resistant limestones enveloped by more soft claystones and marls. Limestones of organogenous and chemical origin indicate a marine milieu as their origin - the former was formed in shallow, the latter in deep sea, in the Jurassic period. In a small cliff opened by an abandoned open pit near Beňatina village, it is possible to collect different fossils such as Crinoidea, Globigerina, Belemnites and rather rare Ammonites (Schlögl et al., 2004).

Neogene Volcanics presented by the Vihorlatské vrchy Mts. cover the majority of the western and southern part of the study area. The Vihorlatské vrchy Mts., similarly to other Neogene volcanic mountains, are typically made of stratovolcanic structure - individual volcanoes are composed of alternating beds of lava flows and volcanoclastics. In the south-eastern part of Vihorlatské vrchy Mts., the following stratovolcanoes are present: Vihorlat, Sokolský potok, Morské Oko, Diel and western part of the Popriečny volcano (its eastern part is situated in the territory of the Transcarpathian region of Ukraine). The majority of volcanites mostly consists of andesites, bazaltic andesites of different composition (pyroxenic, hyperstene-augitite, pyroxene-hornblendite, etc.) and structures (fine to coarse porphyric, pilotaxitic, etc.). Subvolcanic bodies are composed of diorite and diorite-porphyry. In addition, the composition of volcanoclastics is variegated: tuffs, volcanic sandstones, breccias, agglomerates and their mixtures are all present (Žec et al., 1997).

The East Slovakian Neogene Basin, the northernmost salient of the Pannonian Basin, is present on the southern rim of the area. Sedimentary infill of the basin is composed of marine, lagoon and lacustrine sediments (sands, clays, marls, gypsum, halite and lignite). Off-shore sediments of volcanic origin (tuffites and epiklastics of neighbouring volcanites) are also present (Biely et al., 1996).

In the year 1960, according the 'Russian model', so called 'schlich prospections' (panned / heavy minerals concentrate) exploring works were realized in the NE part of the Vihorlatské vrchy Mts., in the Ublianka river-basin. Presence of float gold was recorded in the alluvium of the Stežná brook and its tributaries up to the village Ruská Bystrá (Slávik, 1967). The regional prospection programme Vihorlat - Popriečny was planned on the basis of a local panned concentrate prospection. During this work, presence of the above mentioned gold in the Krynica Unit of the Magura Group (Outer Carpathians Flysch) was confirmed in the NE foothill of the Vihorlatské vrchy Mts. Technical works confirmed the connection between the gold and the detritical beds, especially in the basal parts of the sandstone layers (Slávik, 1969). Later, it was recognised that the presence of gold is much more extensive. It is bound on the Lower to Middle Eocene facies of the Strihovce beds of the Krynica Unit in the area from Ruská Vol'a (near Čirč) to the Ruský Hrabovec villages. Near Ruská Bystrá, the dimensions of float gold varied from microscopical size up to $2.5 \mathrm{~mm} \times 0.75 \mathrm{~mm} \times$ 0.4 mm (Slávik, 1969; Križáni, 1987). The chemical composition of float gold grains was detemined in the first phase of research: the surficial layer of grains reached purity from 950 to 980 , inner (core) parts from 720 to 750 and small float gold up to 960 (Slávik, 1969).

During a following geochemical prospection, enhanced gold content was detected also in areas of Remetské Hámre - Morské Oko, Diel and elsewhere (Bacsó, Ďud'a, 1988).

Relatively frequent presence of corundum in the form of pale-blue crystals was detected in panned concentrates (Slávik, 1970).

Presence of sulphidic mineralisation was also recorded in the eastern part of Vihorlat Mts.: fine impregnations and veinlets of cinabarite are present in sandstones of Paleogene in the vicinity of volcanites present, near the Ladomirov village. Cinabarite was found northwards from Jovsa and Poruba pod Vihorlatom and also at Morské Oko lake near Remetské Hámre (Bacsó, Ďud'a, 1988). Based on the geochemical exploration results, a drilling exploration was carried out in the locality of Morské Oko - Kapka (Bacsó, 1971) resulting in the discovery of low-grade polymetalical mineral deposit (Bačo, Dud'a, 1988) and absolutely new Bi-Te-Se-S minerals, which can be found near the Poruba pod Vihorlatom village. 


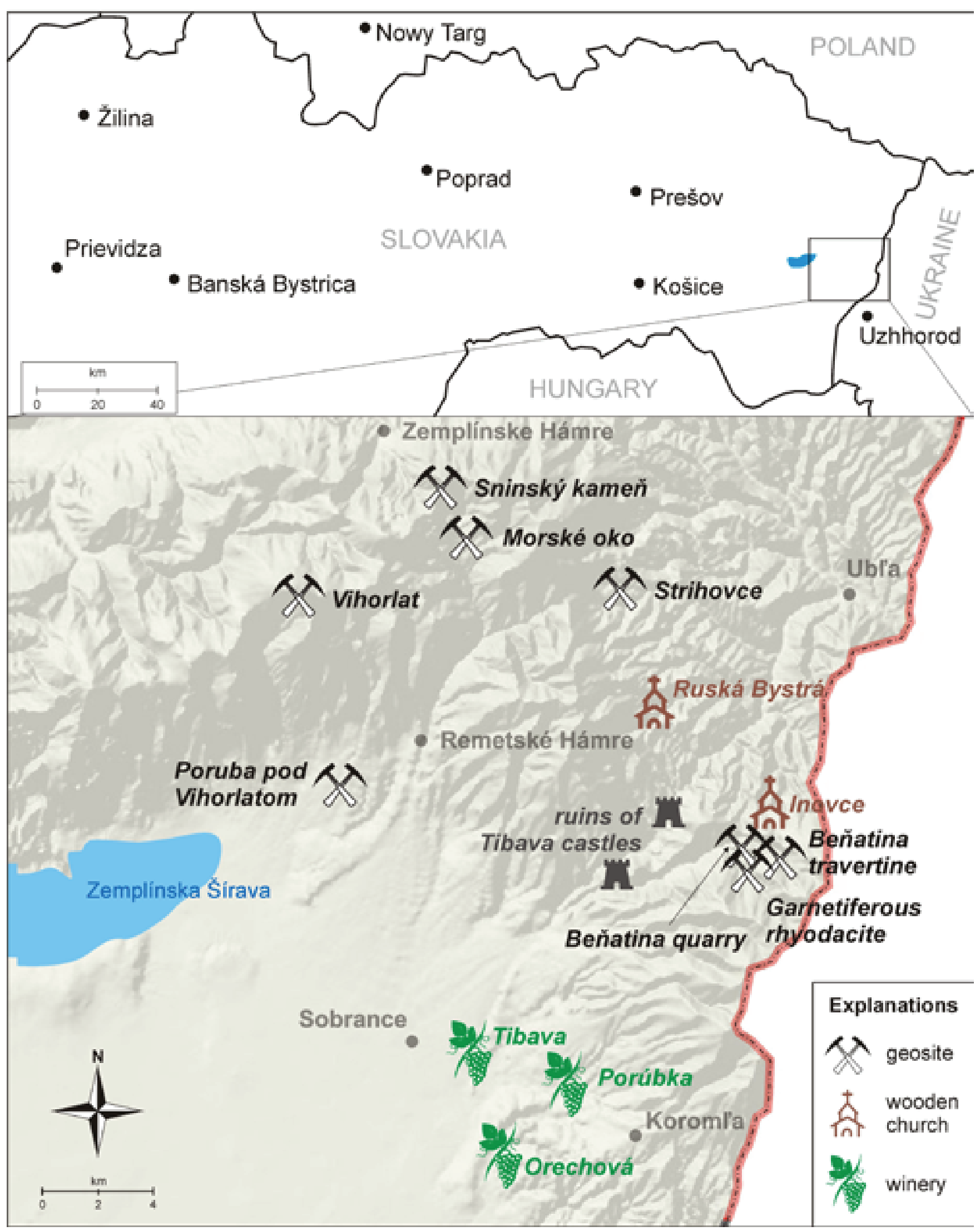

Fig. 1. Location of the study area (Upper Zemplín region, Slovakia) with significant sites (arcgis.com, modified) • Lokalizacja obszaru badań - Górny (górzysty) Zemplin, z zaznaczonymi ważniejszymi obiektami (wg arcgis.com, zmienione) 


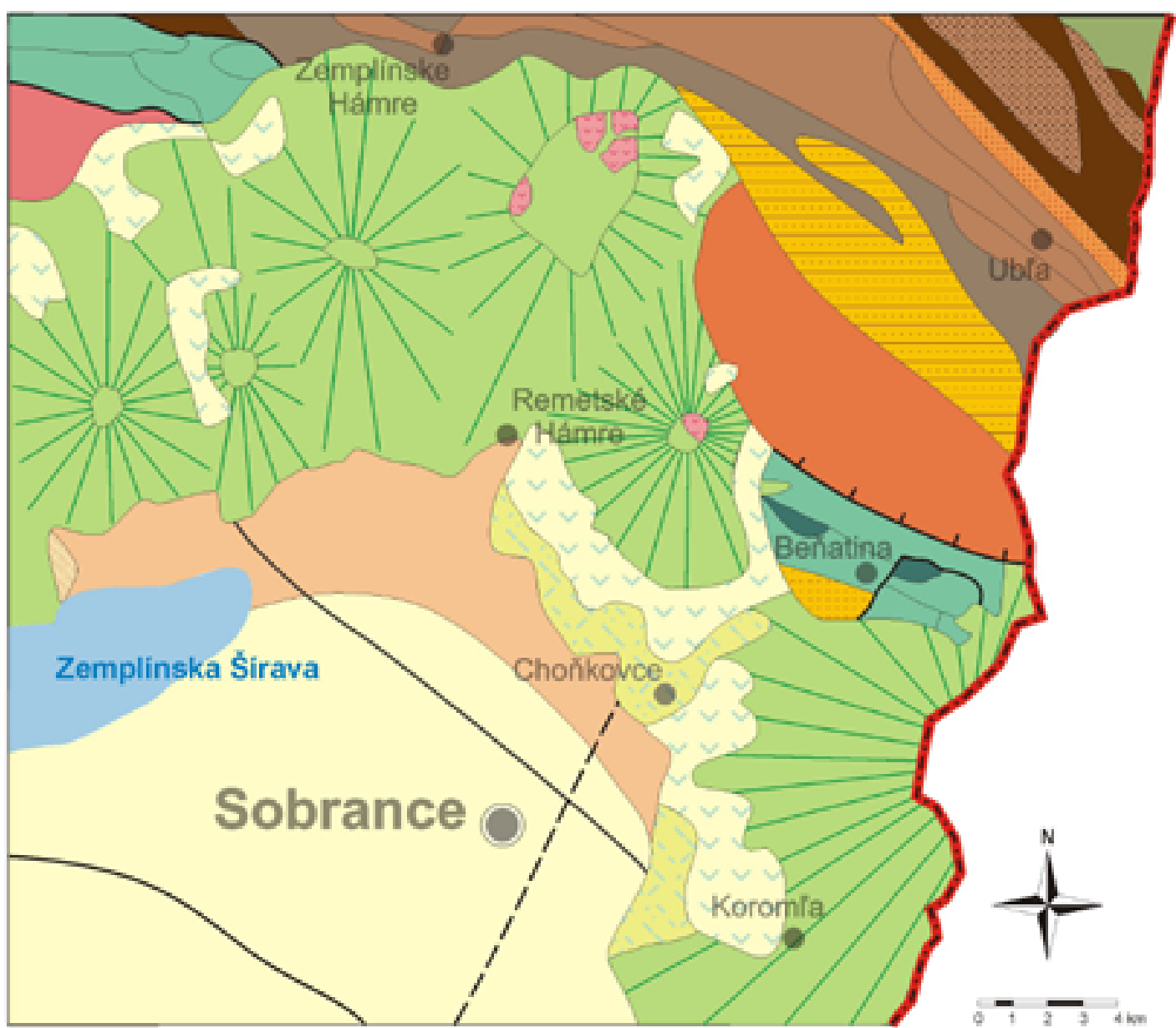

Neogene

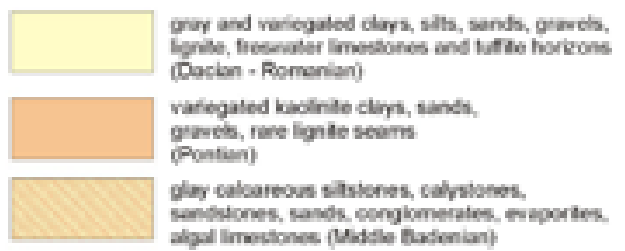

Middle Miocene andesite voleanics

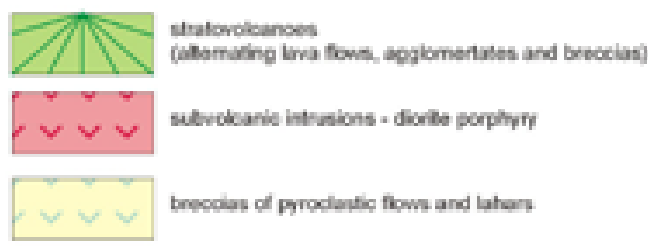

Pieniny Klippen Belt

\begin{tabular}{|c|}
\hline 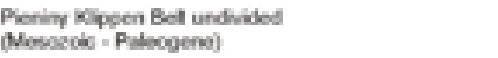 \\
\hline $\begin{array}{l}\text { spotod limestoves, erinoidal and nodular limestones } \\
\text { (Finemutan - Thinonian) }\end{array}$ \\
\hline
\end{tabular}

\section{Late Creataceous and Paleogene of the Inner Carpathians}

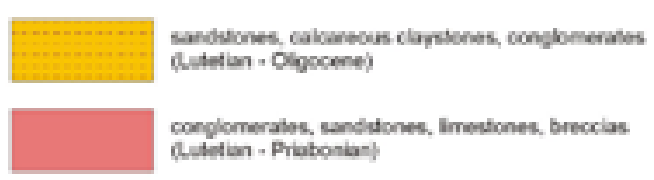

Cretaceous and Paleogene of the Outer Carpathians

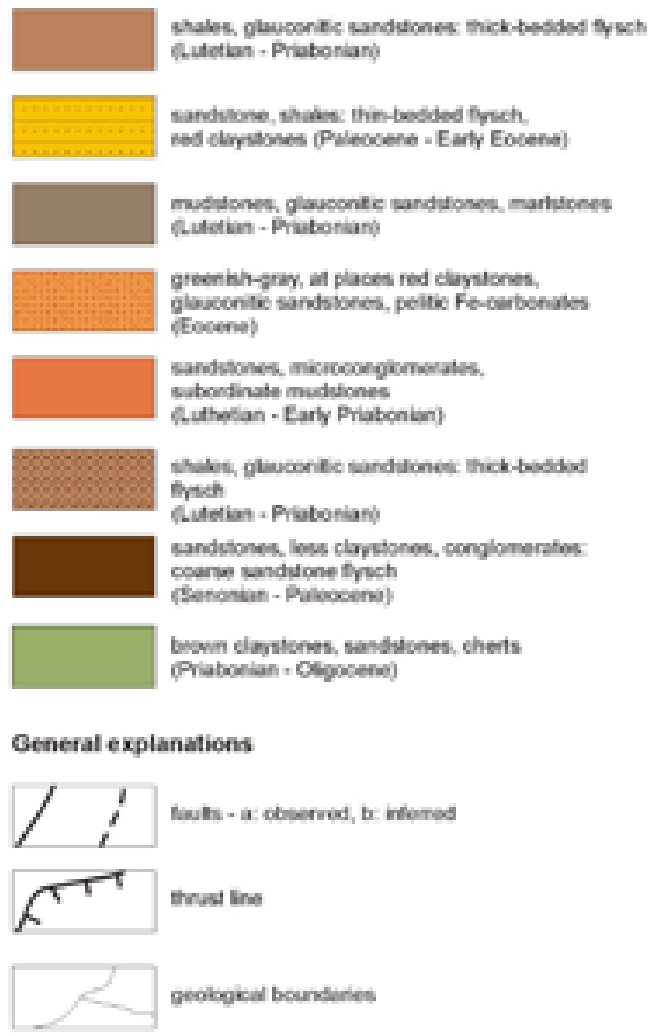

Fig. 2. Geological map of the studied area (after Bezák et al., 2004) • Mapa geologiczna obszaru badań (wg Bezák et al., 2004) 


\section{Geosites of the area}

Based on general overview of the area, it can be assumed that studied region has many geo-attractive locations. The following text describes the most significant places present in the area (Fig. 1).

The Vihorlatské vrchy Mts. are the westernmost part of the Vihorlat - Gutin mountain chain, which passes through the Transcarpathian region of Ukraine and ends in NW Romania. This volcanic belt is young. It arose in the Neogene (about 16-6 My ago), so that there are well preserved volcanic phenomena. Here, we can observe and study about 20 different small-scale features of volcanic relief (e.g. volcanic necks, lava flows etc.). In following text, two large-scaled sites, which will attract the visitor's attention 'for the first sight' - Vihorlat hill and Sninský kameň hill, are described.

Poruba pod Vihorlatom is a very important mineralogical locality, where the following Bi-Te-Se-S minerals were described.

Bismutoferrite $\left(\mathrm{BiFe}_{2}\left(\mathrm{SiO}_{4}\right)_{2}(\mathrm{OH})\right)$ Yellow and yellowish-brown pulverous coatings on telurides (vihorlatite, telluronevsite) were preliminarily identified as bismutoferrite (Szakáll et al., 2013). Dimensions of its platelets are about $40 \mu \mathrm{m}$. They form together with illite aggregates up to $2 \mathrm{~mm}$.
Ingodite $(\mathrm{Bi}(\mathrm{S}, \mathrm{Te}))$ was described from this locality in association with telluronevskite and vihorlatite (Ďud'a, Ozdín, 2012).

Pilsenite $\left(\mathrm{Bi}_{4} \mathrm{Te}_{3}\right)$ - up to few mm large black-grey lamellae of pilsenite was found in this locality in intensively hydrothermally altered andesite.

Telluronevskite $\left(\mathrm{Bi}_{3} \mathrm{Se}_{2} \mathrm{Te}\right)$ - a mineral described from the territory of Slovakia for the first time. Its flakes have steelgray to black color and metallic luster, and dimensions of flakes reach up to $4 \mathrm{~mm}$. It is present in a form of a fine impregnations in so called secondary quartzites - intensively altered (silicified) rocks locally cut by a thin veinlet of quartz and calcite. Telluronevskite is associated with quartz, boehmite, diaspor, clay minerals, pyrite, pyrrhotite, chalkopyrite and stannite (Ďud'a, Ozdín, 2012).

Vihorlatite $\left(\mathrm{Bi}_{24} \mathrm{Se}_{17} \mathrm{Te}_{4}\right)$ - mineral newly discovered and accepted by IMA in 2007 (Skála et al., 2007). Up till now, it was known only from this locality. It is present in fine impregnations and veinlets in silicified strongly alterated volcanic rocks in association with telluronevskite and other up to now not identified Bi-Te-Se-S phases. Vihorlatite (Fig. 3) comprises monomineral grains. Otherwise it is present in intergrowth with other Bi-Te-Se-S minerals. It is present in a form of lamellae and flakes with dimensions up to $1 \mathrm{~mm}$, having steelgrey colour and a strong metallic lustre (Ďud’a, Ozdín, 2012).

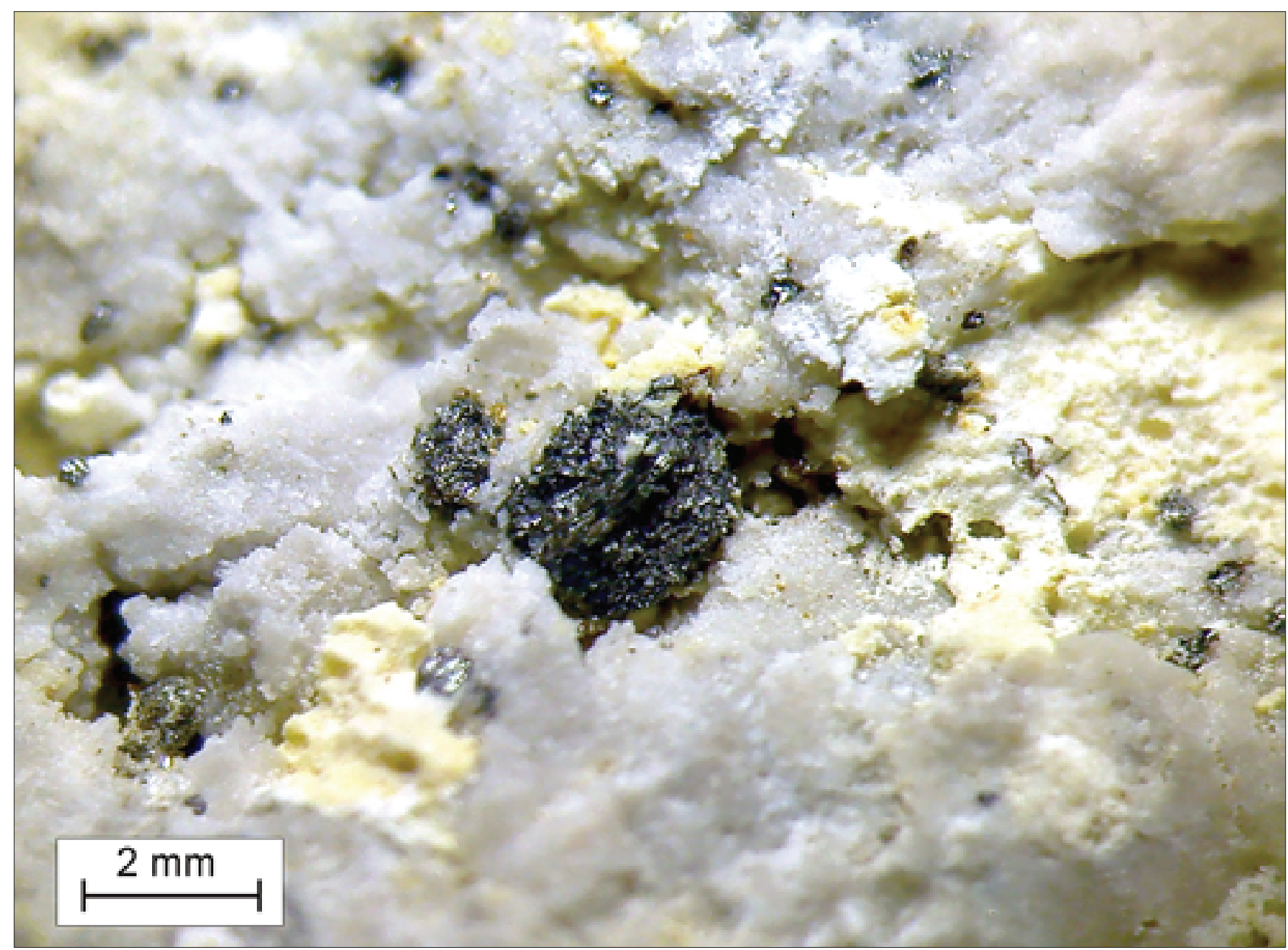

Fig. 3. Vihorlatite mineral, photo S. Kováč • Skupienie virholatytu, fot. S. Kováč 

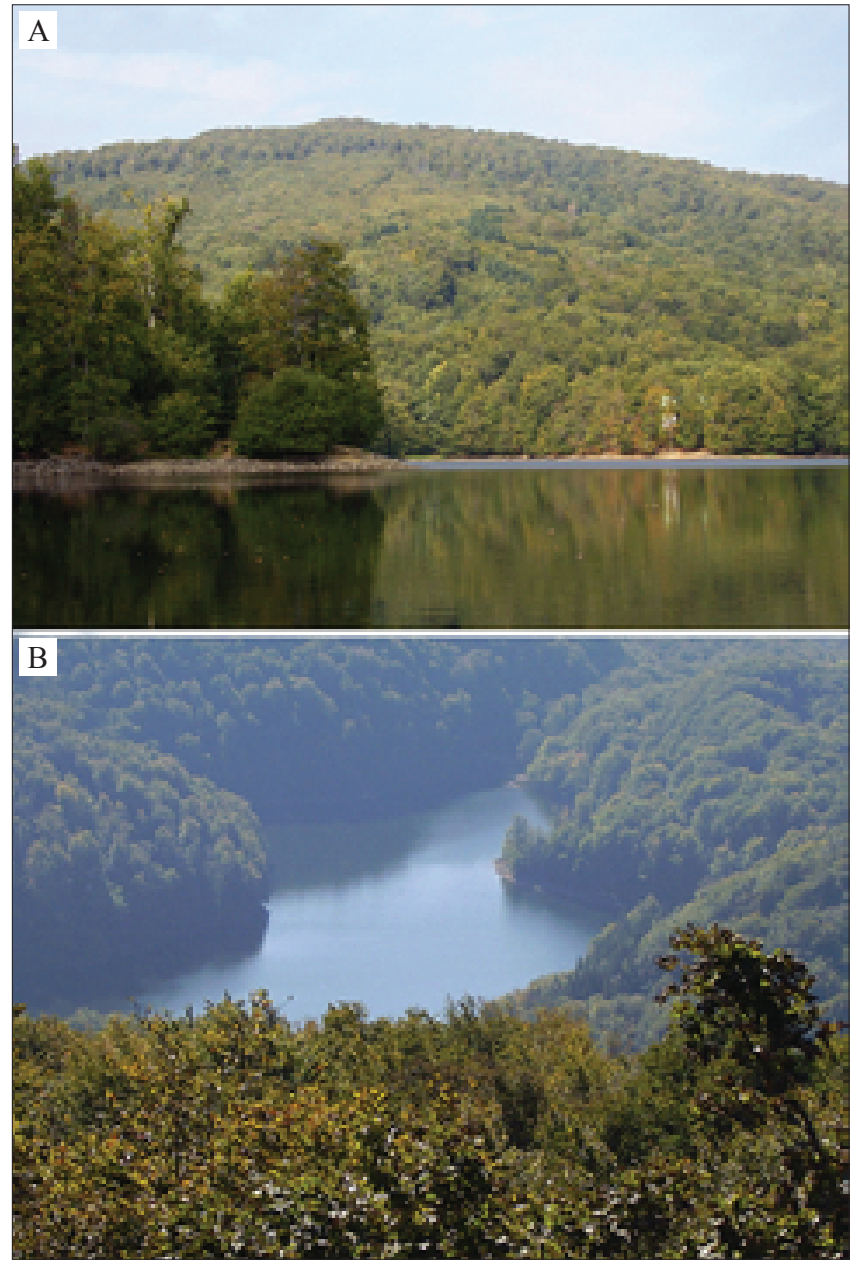

Fig. 4. Morské Oko - landslide dammed lake: $\mathrm{A}$ - view from the lake shore, B - view from the Sninský kameň hill, photo B. Baláž - Morskie Oko - jezioro osuwiskowe: A - widok z brzegu jeziora, B - widok ze wzgórza Sniński Kamień, fot. S. Baláž

Morské Oko - Kapka. An outcrop of a secondary quartzites body was caught during the exploration works oriented on polymetallic mineralisation at the locality of Morské Oko - Kapka (Fig. 4). Its dimensions reach approx. $350 \mathrm{~m} \times 200$ $\mathrm{m}$. These metasomatites are flecked light grey, greenish and pinkish rocks, composed of rich mineral association, representing apical parts of diorite porphyry intrusion, which is connected with hydrothermal activity in the central volcanic zone of Morské Oko stratovolcano (Žec et al., 1997).

Metasomatites are beside quarz composed of the following minerals: ammonian hydromica (Derco et al., 1977) - the now new mineral species tobelite, andalusite, apatite, diaspor, dumortierite, fluorite, kaolinite, corundum (sapphire), monazite, rutile, sillimanite, tridymite, tourmaline a.o. We will shortly characterize the most interesting of them.

Andalusite $\left(\mathrm{Al}_{2} \mathrm{SiO}_{5}\right)$ has a special position in metasomatites from the locality of Morské Oko - Kapka, because locally it is composed of up to $30 \%$ of its mass. It is present in association with topaz and dravite. Andaluzite forms pinkish prismatic crystals reaching up to $0.4 \mathrm{~mm}$, scarcely up to $1.6 \mathrm{~mm}$ (Bacsó, 1971). It is present also in metasomatites on the locality Porubský potok near Poruba pod Vihorlatom (Bacsó, Ďud'a, 1988).

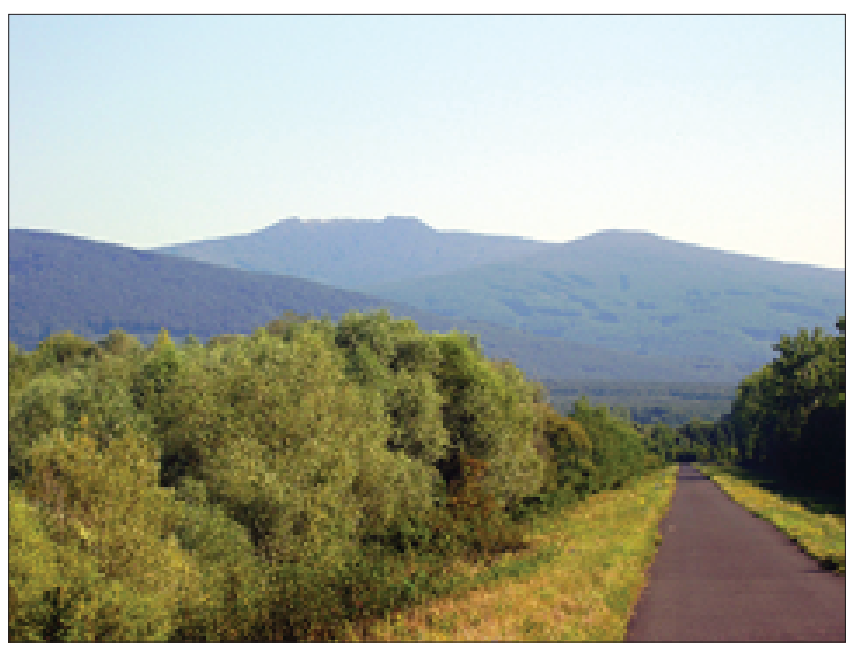

Fig. 5. Vihorlat hill - the highest peak of the Vihorlatské vrchy Mts., photo B. Baláž • Wzgórze Virholat - najwyższy szczyt Gór Virholackich, fot. B. Baláž

Corundum $-\mathrm{Al}_{2} \mathrm{O}_{3}$. It is abundant in metasomatites from Kapka, too (Bacsó, 1971). Corundum is present in a form of grains with dimensions up to $3 \mathrm{~mm}$ ingrown, in a quarz together with diaspor, andalusite and topas. Sometimes it is present as a cask - or spindles-formed crystal, of the colour black, black-blue and violet-red.

Tobelite - $\left(\mathrm{NH}_{4}, \mathrm{~K}\right) \mathrm{Al}_{2}(\mathrm{Al}, \mathrm{Si})_{3} \mathrm{O}_{10}(\mathrm{OH})_{2}$. Originally this mineral was described by Kozáč et al. (1977) in the locality of Morské Oko - Kapka as an 'amonium hydromica' in association with quartz and boehmite from 'secondary quartzites', where it composes an essential part of some variety of quartzites. The mineral was not studied for more detail nor identified. Later, a similar mineral was studied by Higashi (1982) on the locality of Tobe (Shikoku Island, Japan) and named according to the locality as tobelite. Here it is also present in a quartz or in quartzite as small $(0.01 \mathrm{~mm})$ crystals in association with clay minerals. Up till the present, this mineral was identified only in four localities in the world (Dud'a, Ozdín, 2012).

Topas $-\mathrm{Al}_{2} \mathrm{SiO}_{4} \mid(\mathrm{F}, \mathrm{OH})_{2}$. This mineral is the most widespread in the locality of Morské Oko - Kapka. It is the main constituent of the so called topas-quartz-andalusite metasomatites, locally containing diaspor, boehmite and corundum (Bacsó, 1971). Topas is present sporadically in the form of yellowish to smoky-coloured prismatic crystals up to $1 \mathrm{~cm}$ long. It is present in the locality of Porubský potok (creek) near Poruba pod Vihorlatom (Bacsó, Ďud'a, 1988).

Zunyite - $\mathrm{Al}_{13} \mathrm{Si}_{5} \mathrm{O}_{20}(\mathrm{OH}, \mathrm{F})_{18} \mathrm{Cl}$. Its existence from the metasomatites in the locality of Morské Oko - Kapka and Porubský and Sokolský potok near Poruba pod Vihorlatom is doubtable (Bacsó, Ďud'a, 1988).

Vihorlat hill. Vihorlat (1075.4 $\mathrm{m}$ a.s.1.) is the highest stratovolcano in the Vihorlatské vrchy Mts (Fig. 5). It is surrounded by lower heights such as Malé Trstie (965.4 m a.s.1.) and Ladovisko (893.8 $\mathrm{m}$ a.s.1.), which run out to the lateral branches. Its southern slope is covered by a blocky scree. The peak alone presents a central protrusion (tholoid?), which is built of middle porphyric pyroxenic andesite with blocky disintegration. Volcanic products of the Vihorlat stratovolcano are situated in a hanging wall of effusive - explosive products of the Morské Oko and Sokolský potok (creek) stratovolcano activity (Žec et al., 2001). 
There is a very nice panorama view from the top of Vihorlat hill on the whole of the Vihorlatské vrchy Mts., eastwards to the Popriečny hill and Ukrainian Poloniny Mts., southwards to Zemplínska Šírava dam, northwards to the Lower Beskids and Bukovské Mts., westwards to the Slanské Mts. And, with, good visibility to the Králova hol'a (in Nízke Tatras Mts.) and High Tatras, too.

Sninský kameň hill. Central cauldron-shaped depression (caldera) of the Morské Oko stratovolcano is encircled by a discontinuous rim of massive lava flows, which formed robust forms of Roh, Fetkov, Nežiabec, Motrogon, Lysák, Múr and Sninský kameň hills.

Sninský kameň ('Snina Stone') (1005 m a.s.1.) is a relict of lava flow to the NW from Morské Oko Lake. Remnants of lava flow build rocky cliffs, with heights up to $20 \mathrm{~m}$ and lengths up to $300 \mathrm{~m}$. These cliffs consist of middle - to coarsely - porphyric pyroxenic andesite with a mural jointing (Žec et al., 2001).

From the top of the Sninský kameñ is an excellent panoramatic view of Morské Oko Lake and also of the mountain ranges in NE Slovakia (Bukovské Mts., Lower Beskids Mts. and Nastaz mountain ridge), SE Poland (Bieszczady Mts.), W Ukraine (e.g. Polonina Runa, Volcanic Carpathians etc.).

Beňatina quarry. An abandoned limestone Beňatina quarry (Fig. 6) is situated about $800 \mathrm{~m}$ to the NE from the village church on the right side of the road to Inovce. Here, organic limestones of the Czorsztyn Unit were quarried. There a complete sequence of Lower to Upper Jurassic (Oxfordian) succession of limestones was uncovered, well-evidenced by ammonite fossils. Some of the stratigraphic units were re-evaluated by Schlögl et al. (2004) - e.g. Dolné Myny beds (?Hettangian - Early Sinemurian) or Allgäu beds (Upper Sinemurian - Upper Pliensbachian / Domerian). Some were newly defined as: sandstones and marls (Lower Piensbachian / Domerian) and red marls (Toarkian), both belonging to the Hôrka group of strata.

The lower Cretaceous part of the succession responds to the Nižná Formation, which consists of different beds as e.g. crinoidic limestones, synsedimentary limestone breccias and marls, with abundant organodetritic material derived from an Urgonian shallow-water carbonate platform.

The Beňatina cliff differs from a typical succession of cliff development. This succession could be interpreted either as a variety of the Czorsztyn Unit (Pieniny Klippen Belt) succession and, as such, to be located in the northern part of the basin, or as a succession bedded on the southern rand of the Pieniny cliff basin. Some of were lesser known up until now as Lower - to Middle Jurassic ammonites from the Western Carpathians and include species like Lytoceratidae (Alocolytoceras), Arietitidae (Coroniceras), Hildoceratidae (Frechiella) and Graphoceratidae (Ludwigia, Graphoceras, Brasilia) (Schlögl et al., 2004).

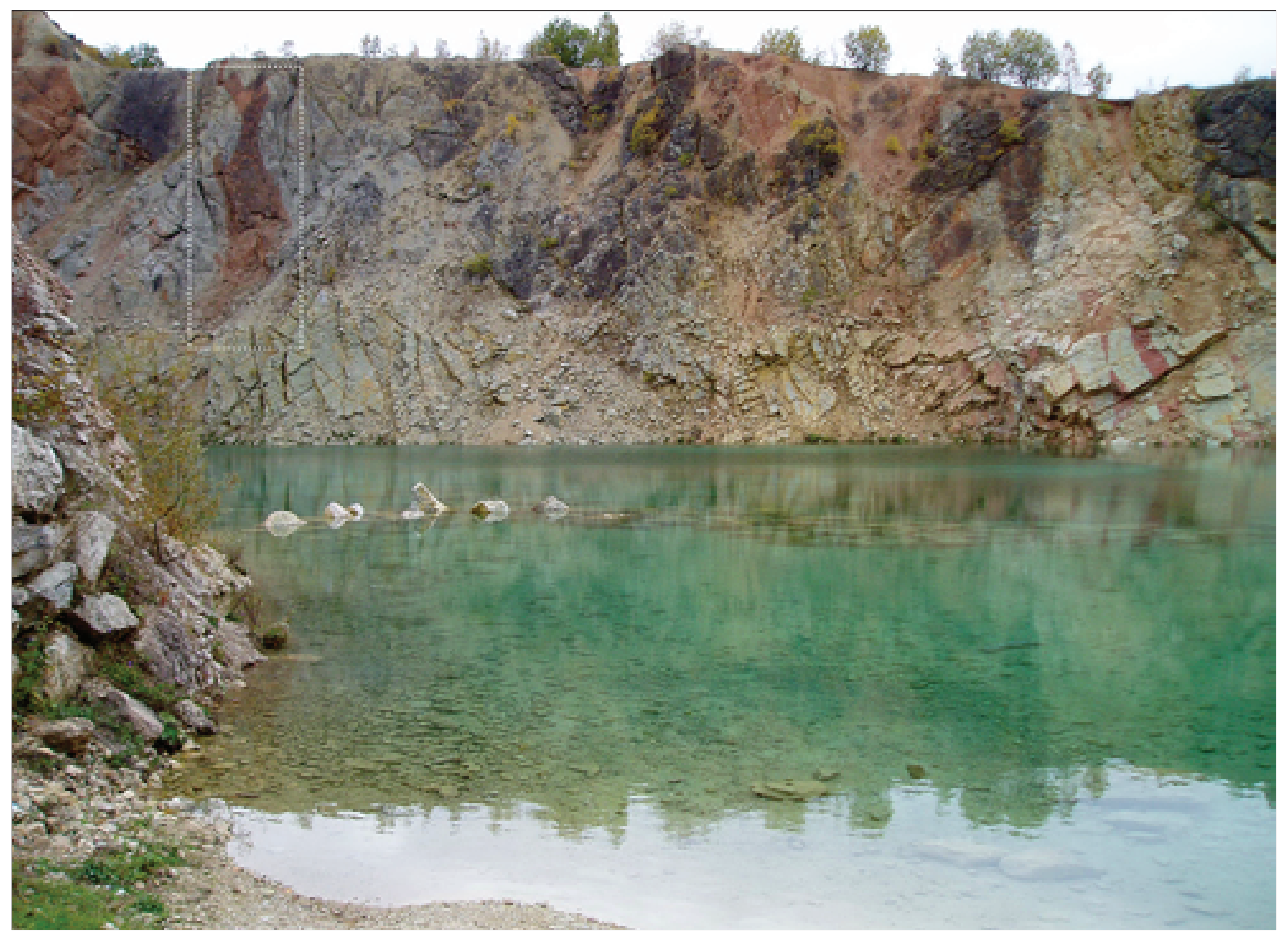

Fig. 6. Beňatina quarry, 'whale' picture highlighted in white rectangle, photo B. Baláž • Kamieniołom Benantina, „obraz wieloryba” zaznaczony kwadratem, fot. B. Baláž 
The quarry was popular for its almost 5 meters long 'whale picture' (Fig. 5) on the wall. This 'picture' was created by unequal leaching of iron oxides in limestone. Nowadays, it is popular serving the public as a beautiful natural swimming pool.

Garnetiferous rhyodacite. An extrusive body of garnetiferous rhyodacite of Sarmatian age (12 $\pm 05 \mathrm{My})$, that can be found in the Beňatinská voda creek valley. This body represents a footwall of explosive-effusive products of the Popriečny stratovolcano. The inner structure of the body is well exposed in a small abandoned quarry on its southern rim (Žec et al., 1997).

Garnets from rhyodacitic (former: rhyolitic-Slávik, 1970) rocks come from a cupola and also partially from xenotuffs, which present basal volcanogenic beds in the Beňatinská voda valley. Garnet dimensions reach according to Slávik (1.c.) $0.2 \mathrm{~cm}$ to $1 \mathrm{~cm}$. They are dark red-brown. Later, these garnets were determined as almandine $-\mathrm{Fe}^{2+}{ }_{3} \mathrm{Al}_{2}\left(\mathrm{SiO}_{4}\right)_{3}(\mathrm{Ja}-$ kabská et al., 1973; Brousse et al., 1972).

Beňatina travertine - About $1.5 \mathrm{~km}$ eastwards from the Beňatina quarry is a down slope forest road, with a Beňatina travertine - the easternmost travertine location in Slovakia. This travertine cascade is located on the area of about 0.24 ha and is still active. Its surrounding is interesting also for its malacofauna. In the year 1989, it was declared as a state protected Natural Monument.

Orechová. Lava flows of the Popriečny stratovolcano formed directionally oriented bodies with average thickness of $15-25 \mathrm{~m}$. In the quarry near the Orechová village, it is possible to see characteristic closing of fluidality planes, which correspond to the existence of a communication channel. Here, during the final stage of the lava flow solidification, more fluid lava flowed.

\section{Cultural-historical sites of the area}

Besides variegated geological structures of the region with interesting geosites, there are several cultural-historical sites, including castle remnants, wooden churches and wineries, which support the overall attractiveness of the area.

Castle remnants. Two castles were built in the study area, in eastern rim of the Vihorlatské vrchy Mts., both named Tibava: the first one in the village Podhoro and the second one near Choňkovce.

The Castle Tibava, situated in the NE side of the Podhorod' village, was built on a dominating knoll-formed hill of one from a few klippes protruding from under volcanites of the Vihohorlat Mts. The castle was built in the 13th century and served as guarding castle and a safe site for the Tibava manor. As early as in the year 1337 , it is mentioned in historical documents as abandoned. It was demolished in 1715 . This castle was not large - its dimensions reached about $40 \times 15 \mathrm{~m}$. The castle consisted of a round tower (outer diameter $11 \mathrm{~m}$, inner $3 \mathrm{~m}$ ), from a living building with a dimension $9 \times 7 \mathrm{~m}$. Remnants of the walls are thick up to $2,5 \mathrm{~m}$ on the base. Up to the present day, only a few remains of walls, the base of the tower and a gate have been preserved. An access road is still evident (Slivka and Vallašek, 1991).

The castle built near Choňkovce is younger than the previous one in Podhoro roughly by a century. This castle also belonged to the Tibava manor. It is situated northward from the village Choňkovce on a mountain ridge called Borolo (meaning 'cliff'), on the narrow rocky ridge of the NE-SW direction, which is called Hradzisko ('hill-fort'). The mountain ridge is from the NW and SE side limited by a steep slopes. From the NE and SW side, there was castle protected by trenches. The castle was very similar to the previous mentioned. It consisted of an only building, with dimensions $19 \mathrm{~m} \times 5 \mathrm{~m}$ with a walls up to $135 \mathrm{~cm}$ thick. There is a lack of information about its history and downfall (Slivka and Vallašek, 1991).

Wooden Greek-catholic temple of the Holy Bishop Nicolaus from the beginning of 18-th century, Ruská Bystrá. This church (in local Ruthenian dialect 'tserkev') is one from the group of wooden churches of the Slovak part of the Carpathian arc, which were on July 7-th, 2008 inscribed into the World cultural heritage list of UNESCO. These churches are an extraordinary example of the rural religious architecture of the NW part of the Carpathian region, its interethnic and intercultural character on the relative small area.

This temple (Fig. 7) is a three-room bock house building, without an exterior covering, which was built in a reduced form of the so called Lemko-type church. The ground-plan of the church represents a typical composition scheme of rooms (from the E to the $\mathrm{W}$ ): polygonal sanctuary, quadratic aisle and small quadratic anteroom (so called 'babinec' room for old hags). All rooms are covered by a common cut roof with a long covering, so that segmentation of temple is from the outside not visible. There is a robust tower prism disembarking over the anteroom. The tower is completed by a tent-formed roof with a two flattened 'onions' and a threearmed forged cross on the top. A smaller gablet ('sanktusnik'), which has a similar form as the greater tower, is situated over the sanctuary (Sopoliga, 1996).

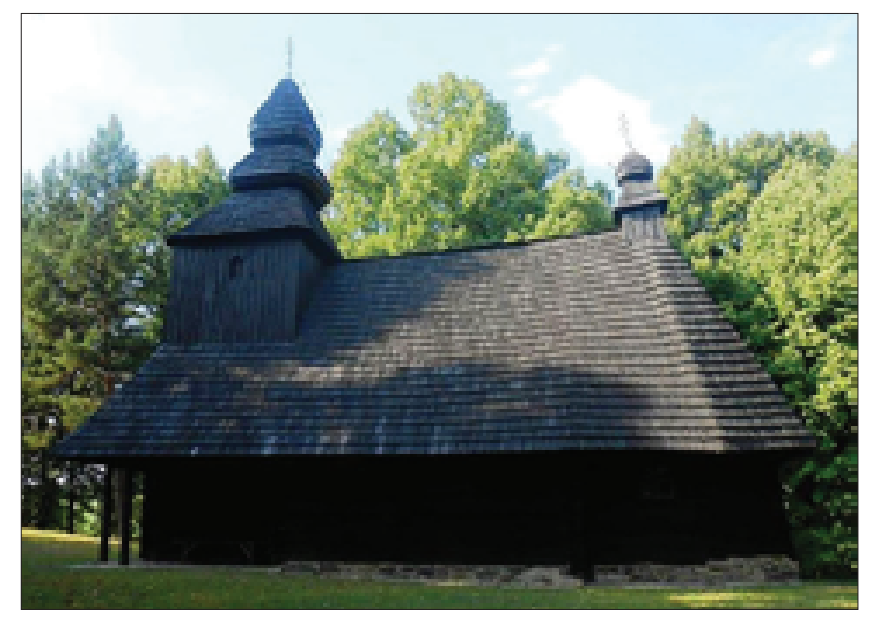

Fig. 7. Wooden church in Ruská Bystrá, photo L' Štrba • Drewniany Kościół w Ruskiej Bystrej, fot. L. Štrba 
This church is a specific expression of a traditional religious architecture as an example of Latin and Byzantine culture conjunction. Temple belongs for a long time to National Cultural Monuments of the Slovak republic. It was at the end of 20-th century completely renewed, its interior was partially reconstructed in 1989.

Wooden Greek-catholic temple of the Holy Michael Archangel from the year 1836, Inovce. This Greek-catholic temple in the near-border village Inovce (enlisted to National Cultural Monuments) is one of the smallest wooden churches, built in the Eastern Slovakia. It was built in the 1836 and consecrated to the Holy Michael Archangel.

This double-towered church has greater tower placed over the anteroom ('babinec') and smaller one over the sanctuary. Both towers are completed by 'onions' with three-armed forged crosses. Entrance to the church nave is through the anteroom. An uncompleted iconostas, where there is one row of icons depicting failing prophets, was placed in the nave due to a lack of space. Icons are also influenced by western style painting, so that there are no typical forms of icons. Due to a space shortage, there is only one deacon's door in the iconostas, which is also untypical. In the second line of icons, depicting religious holidays, not adhered religious cycles are found. There is also present one interesting icon - Pieta, which holds the signature of the author - Mankovič Michael, 1842 (Sopoliga, 1996).

The Sobrance viniculture region. The Sobrance region has outstanding conditions given by its geographical localization and mother rocks of soil substrate. The region is situated on the slopes of the southern Vihorlatské vrchy Mts. and southwestern slopes of the Popriečny stratovolcano. The hills are built-up by andesite volcano streams (leucocratic andesite of the Petrovce formation), epiclastics and pyroclastics of andesites. At the foot of the mountains, eolic-deluvial sediments (loess clays) and loamy-rocky-boulder deluvials are deposited (Žec et al., 1997). Substrates for vine-growing are composed of loamy-rocky soils on the volcanites, loesses and deluvials. The soils have sufficient amounts of chemical components, with basic biogenic elements, very suitable for winegrowing.

Within the Sobrance winegrowing area, there are several superb wineries: in Orechová a private company Regia TT Ltd., which belongs to larger winegrowers in the area. The company cultivates about 55 hectares of its own vineyards. Newly planted out are approx. 30 ha. Production of the Regia TT consists of prevailingly attributive wines (i.e. late harvest, grape selection, raisin collection and ice wine) from the following white (Grüner Veltliner, Rheinriesling, Welschriesling, Müller Thurgau, Chardonnay, Sauvignon blanc, Gewürztraminer, Traywell, Pinot Gris) and also red (Blaufränkisch, Sangiovese, Cabernet Sauvignon, Dunaj and Neronet) sorts of grapes. Besides these wines, the winery also produces sparkling (saturated) wines.

The Pivnica Tibava Ltd. Winery operates in Tibava and Sobrance as the greatest winegrower in the area with an acreage of 350 ha. This winery produces high grade attributive wines from white (Grüner Veltliner, Rheinriesling, Welschriesling, Müller Thurgau, Chardonnay, Sauvignon blanc, Gewürztraminer, Pinot blanc, Pinot gris, Pálava and Moravian Muscat) and red (Blaufränkisch, Sangiovese, Cabernet Sauvignon, Alibernet, Zweigeltrebe and Neronet) sorts of grapes. They produce a wide spectrum of wines - from table wine up to ice wine.

The wine producing company Fundus Regius has its seat and vineyards in the small village of Priekopa situated north-eastwards from Sobrance. This smaller company owns about 15 ha of vineyards, from which they produce about 10.000 liters of high quality attributive wines from the following sorts of grapes: Pinot gris, Rheinriesling, Rumín (hybrid of Pinot gris and Gewürztraminer), Sauvignon blanc, Gewürztraminer, Cabernet Sauvignon and Blaufränkisch (Baláž, Rybár, 2006).

\section{Conclusion}

As the concept of geoparks becomes more popular in different parts of the world, geotourism grows rapidly worldwide. However, besides these relatively extensive areas, there are many regions of geotourist significance of smaller scale that also deserve attention when discussing overall geotourist development. As shown in this article from the example of the Upper Zemplín region, a variegated geological structure, with interesting geosites of different types and rich a cultural-historical background is an adequate prerequisite for the 'next-step' of geotourist development, e.g. via geopark establishment. Here, it should be mentioned that the studied area does not have a 'classical' extent of a geopark, therefore we propose a new concept - a small-scale geopark, which is based on the principles of a classical geopark, but is located within a relatively smaller area. As such, all the activities carried out in a classical geopark, resulting from its definition (UNESCO, 2015) will also be realized in the small-scale geopark, but to a lesser extent.

The studied area also contains flat elongated mountain ridges belonging to the Nastaz subunit of the Bukovské vrchy mountains area, covered by beech forests. A very nice example of a primeval beech forest located here is called Havešová, which is registered on the UNESCO List of World Natural Heritage (Baláž et al., 2014).

It is necessary to mention here, that the description of the most significant locations of the area is only the first step that should be followed by a systematic geosite inventory, an evaluation of geosites and its overall geotourist potential. Therefore, a discussion about small-scale geoparks should be opened, not only between professionals dealing with this issue, but especially when focusing on regions similar to the one described in this article. An effective implementation of this concept may lead to the overall development of the area and help to protect its geological heritage. 


\section{References (Literatura)}

Bacsó Z., 1971. Nové minerály a nové surovinové možnosti Vihorlatu. Mineralia Slovaca, 3: 247-270.

Bacsó Z., Ďud’a R., 1988. Metalogenéza a rudné formácie rudného pol’a Remetské Hámre Mineralia Slovaca, 20: 193-220.

Baláž B., Rybár P., 2006. Wine, geology and tourism. Geoturystyka, 5: 13-28.

Baláž B., Štrba L., Lukáč M., Drevko S., 2014. Geopark development in the Slovak Republic - alternative possibilities. In: SGEM 2014 - International Multidisciplinary Scientific GeoConferences: Ecology and Environemntal Protection, 2: 313-320.

Bezák V., Broska I., Ivanička J., Reichwalder P., Vozár J., Polák M., Havrila M., Mello J., Biely A., Plašienka D., Potfaj M., Konečný V., Lexa J., Kaličiak M., Žec B., Vass D., Elečko M., Janočko J., Pereszlényi M. Marko F., Maglay J., Pristaš J., 2004. Tektonická mapa Slovenskej republiky (1:500 000), Ministerstvo životného prostredia Slovenskej republiky, Štátny geologický ústav Dionýza Štúra, Bratislava.

Biely A., Bezák V., Elečko M., Gross P., Kaličiak M., Konečný V., Lexa J., Mello J., Nemčok J., Potfaj M., Rakús M., Vass D., Vozár J., Vozárová A., 1996. Vysvetlivky ku geologickej mape Slovenska 1 : 500 000. Vydavatel'stvo Dionýza Štúra, Bratislava.

Brousse R., Bizouard H., Šalát J., 1972. Grenats des andésites et des rhyoilites de Slovaquie, origine des grenats dans les séries andésitiques. Contributions to Mineralogy and Petrology, 35: 201-213.

Derco J., Kozáč J., Očenáš D., 1977. Nové poznatky o mineralógii a genéze sekundárnych kvarcitov lokality Kapka v centrálnom Vihorlate. Mineralia Slovaca, 3: 185-205.

Dud’a R., Ozdín D., 2012. Minerály Slovenska (Minerals of Slovakia). Granit Publishing, Praha.

GGN, 2015. Members list - Global Network of National Geoparks. Available at: http:/www.globalgeopark.org/aboutGGN/list/

Higashi S., 1982. Tobelite, a new ammonium dioctahedral mica. Mineralogical Journal, 11: 138-146.

Jakabská K., Timčák G., Fiačanová E., Činčárová M., 1973. The relation of microhardness to the physical and chemical properties of garnets from volcanic rocks of the West Carpathians. Geologica Carpathica, 24: 177-190.

Jones C.2008, History of geoparks. Geological Society, London, Special Publications, 300: 37-60.
Kozáč J., Očenáš E., Derco J., 1977. Amónna hydrosl'uda vo Vihorlate. Mineralia Slovaca, 9: 479-494.

Križáni I., 1987. Zlato vo flyši a neovulkanitoch východného Slovenska. In: Zlato v Západných Karpatoch, GÚDŠ Bratislava, 139-142.

Schlögl J., Rakús M., Krobicki M., Matyja B.A., Wierzbowski A., Aubrecht R., Sitár V., Józsa Š., 2004. Beňatina Klippe - lithostratigraphy, biostratigraphy, palaentology of the Jurassic and Lower Cretaceous deposits (Pieniny Klippen Belt, Western Carpathians, Slovakia). Slovak Geological Magazine, 10: 241-262.

Skála R., Ondruš P., Veselovský F., Táborský Z., Ďud’a R., 2007. Vihorlatite$\mathrm{Bi}_{24} \mathrm{Se}_{17} \mathrm{Te}_{4}$, a new mineral of tetradymite group from Vihorlat Mts., Slovakia. European Journal of Mineralogy, 19: 255-265.

Slávik J., 1967. Samorodnoje zoloto v magurskom fliše. In: VIII Kongres KBGA. Doklady Mineralia, Geochimija, Beograd, 271-274.

Slávik J., 1969. Geologické a petrografické pomery Vihorlatu a Popričného (PhD Thesis). Archív KGaM BF VŠT Košice.

Slávik J., 1970. Minerály rozsypov vulkanitov Vihorlatu, ich geologický a prospekčný význam Mineralia Slovaca, 2: 231-247.

Slivka M., Vallašek A., 1991. Hrady a hrádky na východnom Slovensku. Východoslovenské vydavatel'stvo, Košice.

Sopoliga M., 1996. Perly l'udovej architektúry. Dino Prešov and ŠMURK Svidník.

Szakáll S., Fehér B., Kristály F., Zajzon N., 2013. Mineralogical mosaics from Carpathian - Pannonian region I. Földtani Közlony, 143(2): 177-188.

UNESCO, 2014. What is a Global Geopark? Available at: http://www.unesco.org/new/en/natural-sciences/environment/earth-sciences/global-geoparks/some-questions-about-geoparks/what-is-a-global-geopark/

Žec B., Kaličiak M., Konečný V., Lexa J., Jacko S., Baňacký V., Karoli S., Potfaj M., Rakús M., Petro L', Spišák Z., Bodnár J., Jetel J., Boorová D., Zlinská A., 1997. Vysvetlivky ku geologickej mape Viholatských a Humenských vrchov 1 : 50000 (Explanations to the geological map of the Vihorlat and Humenské Mts., 1 : 50 000). Vydavatel'stvo D. Štúra, Bratislava.

Žec B., Konečný P., Král' J., 2005. Geologická, vulkanologická a petrologická chrakteristika andezitových dajok a nekov pri Ladomírove (Geological, volcanological and petrological characteristic of dykes and necks near Ladomirov). Mineralia Slovaca, 37: 272-278.

Žec B., Kaličiaková E., Žecová K., Stercz M., Rovňák L., Palko L., 2001. Geologicko-náučná mapa Vihorlatských vrchov. Ministerstvo životného prostredia SR, Štátny geologický ústav D. Štúra, Bratislava. 